University of Nebraska - Lincoln

DigitalCommons@University of Nebraska - Lincoln

Faculty Papers and Publications in Animal

Science

Animal Science Department

2013

\title{
Impacts of a Limit-Feeding Procedure on Variation and Accuracy of Cattle Weights
}

\author{
A. K. Watson \\ University of Nebraska-Lincoln, awatson3@unl.edu \\ B. L. Nuttelman \\ University of Nebraska-Lincoln \\ T. J. Klopfenstein \\ University of Nebraska-Lincoln, tklopfenstein1@unl.edu \\ L. W. Lomas \\ Kansas State University Southeast Agricultural Research Center \\ G. E. Erickson \\ University of Nebraska-Lincoln, gerickson4@unl.edu
}

Follow this and additional works at: https://digitalcommons.unl.edu/animalscifacpub

Watson, A. K.; Nuttelman, B. L.; Klopfenstein, T. J.; Lomas, L. W.; and Erickson, G. E., "Impacts of a LimitFeeding Procedure on Variation and Accuracy of Cattle Weights" (2013). Faculty Papers and Publications in Animal Science. 790.

https://digitalcommons.unl.edu/animalscifacpub/790

This Article is brought to you for free and open access by the Animal Science Department at DigitalCommons@University of Nebraska - Lincoln. It has been accepted for inclusion in Faculty Papers and Publications in Animal Science by an authorized administrator of DigitalCommons@University of Nebraska - Lincoln. 


\title{
Impacts of a limit-feeding procedure on variation and accuracy of cattle weights 1
}

\author{
A. K. Watson,* B. L. Nuttelman,* T. J. Klopfenstein, $*, 2$ L. W. Lomas, $\uparrow$ and G. E. Erickson* \\ *Department of Animal Science, University of Nebraska-Lincoln, Lincoln 68583-0908; \\ and $†$ Kansas State University Southeast Agricultural Research Center, Parsons 67357
}

\begin{abstract}
Cattle weights can be highly variable and are influenced by many factors, including time of weighing, ambient temperature, feed intake, and cattle handling. A protocol of limit feeding has been in use since the $1980 \mathrm{~s}$ that was designed to reduce variation in gut fill due to differences in intakes. Cattle are penned and fed a 50\% hay, $50 \%$ wet corn gluten feed or grain diet (DM basis) at an estimated $2 \%$ of BW for at least $5 \mathrm{~d}$, after which weights are taken on 2 consecutive $d$ and averaged for a limit-fed BW (LFW). For this analysis, full-fed weights (FFW) also were taken before the limit-feeding period while cattle had ad libitum intakes. Data from 18 experiments were used to analyze differences within 2-d LFW and between LFW and FFW. For 10 of the 18 experiments, FFW also were measured on 2 consecutive $d$. Cattle included in this summary were grazing cornstalks, smooth bromegrass pasture, Bermuda grass pasture, fescue pasture, native range, or in a dry lot on a $70 \%$ forage diet. The largest differences between FFW and LFW for individual cattle were -39 to $+44 \mathrm{~kg}$ over all 18 experiments. Differences between 2 consecutive d of LFW were -23 to $+24 \mathrm{~kg}$ for all 18 experiments. Differences between $2 \mathrm{~d}$ of FFW were -14 to $+34 \mathrm{~kg}$ in the 10 experiments measuring FFW on 2
\end{abstract}

consecutive d. There was not a clear relationship between FFW and LFW; each weighing scenario had unique environmental conditions that led to different relationships. Differences in both beginning and ending BW were compounded when calculating ADG. Average daily gain was calculated for 15 of the experiments on the basis of either LFW or FFW. Differences between LFW and FFW ADG were -0.29 to $+0.31 \mathrm{~kg} / \mathrm{d}$. The maximum ADG based on FFW was $1.62 \mathrm{~kg} / \mathrm{d}$. This large ADG, on a forage based diet, was likely due to changes in gut fill rather than tissue gain. These data suggest that handling cattle in a similar manner when weighing is more important than limiting intakes to decrease variance between weights. However, limiting intake before collection of beginning and ending BW better estimates empty body weight of cattle, allowing for a more accurate determination of actual body tissue weight gain. Measuring weights accurately becomes especially crucial when evaluating multiple components within a system (e.g., cornstalks to pasture to feedlot). Feeding a standard diet between these components of the system minimizes differences in gut fill due to treatment and allows for a more accurate determination of each component's contribution to the total system.

Key words: cattle weights, gut fill, limit feeding, multiple weights, weighing variation

(C) 2013 American Society of Animal Science. All rights reserved.

J. Anim. Sci. 2013.91:5507-5517 doi:10.2527/jas2013-6349

\section{INTRODUCTION}

Since the 1920s, researchers have recognized the importance of accurate cattle weights and have debated the best method of obtaining them. There are 3 main sources of variation in cattle weights on different days: variation due to differences between animals, changes in environmental conditions, and residual or

\footnotetext{
${ }^{1}$ A contribution of the University of Nebraska Agricultural Research Division, supported in part by funds provided through the Hatch Act.

${ }^{2}$ Corresponding author: tklopfenstein1@unl.edu

Received February 8, 2013.

Accepted September 3, 2013.
}

technique error (Baker and Guilbert, 1942; Patterson, 1947). Differences between animals can be minimized by using similar age, breed, and size of animals within experiments. Using multiple-day weights can lead to greater precision in weighing cattle (Stock et al., 1983). Changes in environmental conditions include changes in time of weighing, temperature, amount and type of feed consumed, and how the cattle are handled. Differences due to time of weighing and how the cattle are handled can be minimized. Differences in amount of feed consumed, and thus the weight of digestive tract contents, may be the largest source of error in weighing cattle, especially for cattle on bulky, forage-based diets 
(Koch et al., 1958). Obtaining accurate weights enhances researchers' ability to calculate statistical differences and to have repeatability of results (Whiteman et al., 1954; Stock et al., 1983).

The most accurate way of measuring actual tissue weights is to slaughter the cattle and record carcassbased weights (Meyer et al., 1960). Although accurate, this method is costly and impractical for large numbers of cattle on growing studies. Some researchers have implemented a protocol for limit-feeding cattle and then weighing early in the morning on 2 or more consecutive days. This protocol attempts to minimize variability in cattle weights due to rumen fill from changes in feed intake and time of day of weighing. This protocol has been implemented for many years, but differences in BW due to a limit-feeding period have never been verified. Therefore, the objective of this study was to document variation within and differences and relationships between limit-fed and full-fed weights.

\section{MATERIALS AND METHODS}

All cattle were managed in accordance with the protocols approved by the Animal Care and Use Committees at the University of Nebraska and Kansas State University.

Cattle weight data were collected from 8 experiments conducted at the University of Nebraska Agricultural Research and Development Center near Mead, NE, and 10 experiments conducted at the Kansas State University Southeast Agricultural Research Center near Parsons, KS. The 18 forage-based growing experi- ments are summarized in Table 1. At both research stations, cattle on trial had ad libitum intakes and were weighed directly off trial for a full-fed weight (FFW). These same groups of cattle were then fed at an estimated $2 \%$ of BW for at least $5 \mathrm{~d}$, after which limit-fed weights were taken on 2 consecutive $d$ and averaged for an ending limit-fed BW (LFW). In 15 of these experiments, initial LFW were also measured, and ADG was calculated for cattle on the basis of either FFW or LFW. Two of the experiments had initial FFW.

\section{Animal Management}

For all research experiments conducted at the University of Nebraska, a standard protocol is followed to obtain beginning and ending BW on all animals. Cattle are penned for at least $5 \mathrm{~d}$ while being limit fed at an estimated $2 \%$ of BW a diet consisting of $50 \%$ wet corn gluten feed (Sweet Bran, Cargill Inc., Blair, NE) and 50\% hay (DM basis). Cattle are then weighed on 2 or 3 consecutive $\mathrm{d}$ to obtain an average beginning BW. For growing experiments, cattle are again limit fed at $2 \%$ of $\mathrm{BW}$ for at least $5 \mathrm{~d}$ at the conclusion of the experiment and then weighed on 2 or 3 consecutive $d$ to obtain an average ending BW. Cattle are group fed during the $5 \mathrm{~d}$ of limit feeding at an estimated $2 \%$ of BW. Group feeding has the potential to bias weights by allowing dominant animals to consume more than $2 \%$ of BW while limiting shy feeders to less than $2 \%$ of BW. To combat this, cattle are allowed a minimum of $0.41 \mathrm{~m}$ (16 inches) of bunk space per animal during limit feeding. Feed is typically

Table 1. Description of cattle on each experiment

\begin{tabular}{|c|c|c|c|c|c|c|c|c|c|}
\hline Research Station $^{1}$ & Exp. & No. of cattle & ${\text { Beginning } \mathrm{LFW}^{2}}^{2}$ & ${\text { Beginning } \mathrm{FFW}^{2}}^{2}$ & End LFW & End $\mathrm{FFW}^{2}$ & Year & Diet & Duration, $\mathrm{d}$ \\
\hline $\mathrm{UNL}$ & 1 & 45 & 325 & - & 462 & 475 & 2009 & Smooth bromegrass pasture & 168 \\
\hline UNL & 2 & 75 & 308 & - & 475 & 477 & 2011 & Smooth bromegrass pasture & 168 \\
\hline UNL & 3 & 32 & 325 & - & 402 & 399 & 2011 & Native range & 121 \\
\hline UNL & 4 & 116 & - & - & 349 & 345 & 2011 & Native range & 62 \\
\hline UNL & 5 & 257 & - & - & 285 & 283 & 2011 & Smooth bromegrass pasture & 20 \\
\hline UNL & 6 & 231 & 285 & 283 & 375 & 372 & 2011 & Native range & 128 \\
\hline KSU & 9 & 36 & 199 & - & 378 & 377 & 2005 & Smooth bromegrass pasture & 196 \\
\hline KSU & 10 & 36 & 220 & - & 364 & 372 & 2006 & Smooth bromegrass pasture & 161 \\
\hline $\mathrm{KSU}$ & 11 & 36 & 226 & - & 370 & 384 & 2007 & Smooth bromegrass pasture & 182 \\
\hline KSU & 12 & 36 & 205 & - & 377 & 388 & 2008 & Smooth bromegrass pasture & 196 \\
\hline KSU & 13 & 36 & 212 & - & 400 & 416 & 2009 & Smooth bromegrass pasture & 221 \\
\hline $\mathrm{KSU}$ & 17 & 40 & 369 & - & 466 & 469 & 2008 & Bermuda grass pasture & 105 \\
\hline KSU & 18 & 72 & 250 & - & 443 & 456 & 2010 & Fescue pasture & 224 \\
\hline
\end{tabular}

${ }^{1} \mathrm{UNL}=$ University of Nebraska-Lincoln; KSU $=$ Kansas State University. ${ }^{2}$ Full-fed weights (FFW) were measured while cattle had ad libitum intakes, limitfed weights (LFW) were measured after a 5 -d period of restricting intakes to $2 \%$ of BW. 
cleaned up by noon; cattle are then weighed at $0700 \mathrm{~h}$ the following morning, after which they are fed for the day.

For finishing experiments, beginning BW is obtained the same way as growing experiments, but ending BW is determined by carcass weight at the packing plant (no gut fill variation) using a constant $63 \%$ dress to adjust HCW to LFW. Precautions are taken to avoid excessive trim on carcasses, which would affect HCW.

For the 10 experiments done at Kansas State University and included in this summary, cattle were weighed on 2 consecutive $d$ while still on trial to obtain a full ending BW. These cattle were then limit fed for at least $6 \mathrm{~d}$ and weighed on 2 consecutive $\mathrm{d}$ for a limit-fed ending BW. Limit feeding consisted of penning the cattle and feeding a $50 \%$ prairie hay and $50 \%$ grain sorghum or shelled corn diet at an estimated $2 \%$ of BW. All weights, both limit fed and full, were an average of 2 consecutive $d$ of weights. Cattle were penned near scales for the limit-feeding period. Therefore, they traveled a shorter distance to the scales for LFW than FFW. However, they were not moved long distances for the FFW. All weights were taken at approximately $0800 \mathrm{~h}$.

Cattle weights can be influenced by cattle handling both before and during the weighing procedure. The following is a detailed description of how the cattle were handled leading up to both FFW and LFW for the 18 experiments included in this study (Table 1).

\section{Experiment 1}

In October of 2009 single-day full weights were taken on 45 steer calves that had grazed smooth bromegrass pasture for $168 \mathrm{~d}$ (Watson et al., 2012). Cattle were pulled from pasture at $0600 \mathrm{~h}$, moved approximately 0.8 $\mathrm{km}$ to the handling facility, and penned for $1 \mathrm{~h}$ while being weighed (FFW). They were then moved less than $0.4 \mathrm{~km}$ to feedlot pens to be limit fed for $7 \mathrm{~d}$, after which weights were taken on 2 consecutive d. The LFW were taken at $0630 \mathrm{~h}$, and cattle were back in pens by $0730 \mathrm{~h}$.

\section{Experiment 2}

In a similar experiment, 75 steer calves were weighed in October of 2011 after grazing smooth bromegrass pasture for $168 \mathrm{~d}$ (Pruitt et al., 2012). Cattle were pulled from pasture at $0600 \mathrm{~h}$, moved approximately 0.8 $\mathrm{km}$ to the handling facility, and penned for $2 \mathrm{~h}$ while being weighed. They were then moved less than $0.4 \mathrm{~km}$ to feedlot pens to be limit fed for $6 \mathrm{~d}$, after which weights were taken on 2 consecutive d. The LFW were taken at $0630 \mathrm{~h}$, and cattle were back in pens by $0830 \mathrm{~h}$.

\section{Experiment 3}

In May of 2011, 32 steer calves were limit fed for $5 \mathrm{~d}$ and then weighed on 2 consecutive $\mathrm{d}$ to obtain a beginning LFW. They then grazed native range in the Sandhills near Rose, NE, for $121 \mathrm{~d}$. After grazing native range, cattle were moved approximately $0.8 \mathrm{~km}$ to a portable chute and loaded on semitrucks by 1100 h. They were then shipped approximately $322 \mathrm{~km}$ to Mead, NE, and unloaded, and a single-day FFW was taken between 1630 and $1800 \mathrm{~h}$. Cattle were then limit fed for $7 \mathrm{~d}$ in pens less than $0.4 \mathrm{~km}$ from the handling facility, after which LFW were taken on 2 consecutive d. The LFW were taken between 0730 and $0930 \mathrm{~h}$.

\section{Experiment 4}

In June of 2011, 116 steer calves were weighed after mob grazing native range in the Sandhills near Rose, NE, for $62 \mathrm{~d}$. Cattle were moved approximately $0.8 \mathrm{~km}$ to a portable chute and loaded on semitrucks by $1000 \mathrm{~h}$. They were then shipped approximately $322 \mathrm{~km}$ to Mead, NE, and unloaded and a single-day FFW was taken between 1430 and $1530 \mathrm{~h}$. Cattle were then limit fed for $7 \mathrm{~d}$ in pens less than $0.4 \mathrm{~km}$ from the handling facility, after which LFW were taken on 2 consecutive $d$.

\section{Experiments 5 and 6}

In May of 2011, 257 heifer calves were weighed after grazing smooth bromegrass pasture for $20 \mathrm{~d}$ (Exp. 5; Gillespie et al., 2012). For FFW, cattle were pulled from pasture at $0700 \mathrm{~h}$, moved $0.8 \mathrm{~km}$ to the handling facility, and weighed by $1030 \mathrm{~h}$. Cattle were then held in 1 pen, $0.4 \mathrm{~km}$ from the handling facility, to be limit fed for $7 \mathrm{~d}$. Limit-fed weights were taken at $0800 \mathrm{~h}$, and cattle were back in the pen by $1100 \mathrm{~h}$. On the first day of LFW, heifers were also branded while in the chute. Out of this pool of heifers, 231 then went to the Sandhills near Rose, NE, to graze native range until September (Exp. 6; Gillespie et al., 2012). After 128 d of grazing, the heifers were moved approximately 0.8 $\mathrm{km}$ to a portable chute, loaded at $1100 \mathrm{~h}$, and shipped approximately $322 \mathrm{~km}$ to Mead, NE. A FFW was taken between 1630 and $1800 \mathrm{~h}$, after which the calves were penned $0.4 \mathrm{~km}$ from the handling facility and limit fed for $6 \mathrm{~d}$. Limit-fed weights were taken on 2 consecutive $\mathrm{d}$, with cattle pulled from pens at $0700 \mathrm{~h}$, weighed, and returned to pens by $0930 \mathrm{~h}$. For this group of heifers ADG was then calculated for the $128 \mathrm{~d}$ of Sandhills grazing on the basis of FFW beginning and ending weights and LFW beginning and ending weights. 


\section{Experiment 7}

In February 2011, 258 steer calves were weighed after grazing cornstalks for approximately $90 \mathrm{~d}$. Cattle were pulled from the cornstalk field at $0700 \mathrm{~h}$ and moved approximately $1.6 \mathrm{~km}$ on foot to the handling facility, and FFW were taken between 0800 and $1030 \mathrm{~h}$. They were then penned $0.4 \mathrm{~km}$ from the handling facility to be limit fed for $6 \mathrm{~d}$. For LFW, cattle were weighed at $0700 \mathrm{~h}$ and returned to pens by $0900 \mathrm{~h}$.

\section{Experiment 8}

In April 2011, 509 steer calves were weighed after a growing experiment with diets consisting of choice between $60 \%$ grass hay with $40 \%$ alfalfa mix and $70 \%$ straw/cornstalk with $30 \%$ modified distillers grains plus solubles mix (Weber et al., 2012). These cattle were penned less than $0.4 \mathrm{~km}$ from the handling facility and were limit fed for $5 \mathrm{~d}$ in the same pens they were in for the growing study. For both FFW and LFW, cattle were pulled from pens at $0730 \mathrm{~h}$, weighed, and returned to their pens by $1000 \mathrm{~h}$. Both FFW and LFW weights were used to calculate ADG for 258 of these steers. Ending FFW and LFW on Exp. 7 served as initial FFW and LFW for 258 steers on Exp. 8.

\section{Experiments 9 to 14}

In April 2005, 36 steer calves were weighed on 2 consecutive $\mathrm{d}$ after being limit fed for $7 \mathrm{~d}$ (Exp. 9; Lomas and Moyer, 2009). Calves then grazed smooth bromegrass pastures for $196 \mathrm{~d}$, after which FFW were taken on 2 consecutive d. Cattle were then penned and limit fed for $7 \mathrm{~d}$, and LFW were taken on 2 consecutive d. This weighing procedure was repeated in 2006, 2007, 2008, 2009, and 2010 on 36 steer calves grazing smooth bromegrass pastures (Exp. 10, 11, 12, 13, and 14, respectively; Lomas and Moyer, 2009, 2011a).

\section{Experiments 15 to 17}

In 2006, 2007, and 2008, 40 steer calves were weighed on 2 consecutive $\mathrm{d}$ after being limit fed for $7 \mathrm{~d}$ (Exp. 15, 16, and 17, respectively; Lomas and Moyer, 2009). Calves then grazed Bermuda grass pastures for an average of $100 \mathrm{~d}$, after which FFW were taken on 2 consecutive d. Cattle were then penned and limit fed for 6 or $7 \mathrm{~d}$, and LFW were taken on 2 consecutive $\mathrm{d}$.

\section{Experiment 18}

In March 2010, 72 steer calves were weighed on 2 consecutive $\mathrm{d}$ after being limit fed for $7 \mathrm{~d}$ (Lomas and Moyer, 2011b). Calves then grazed fescue pastures for

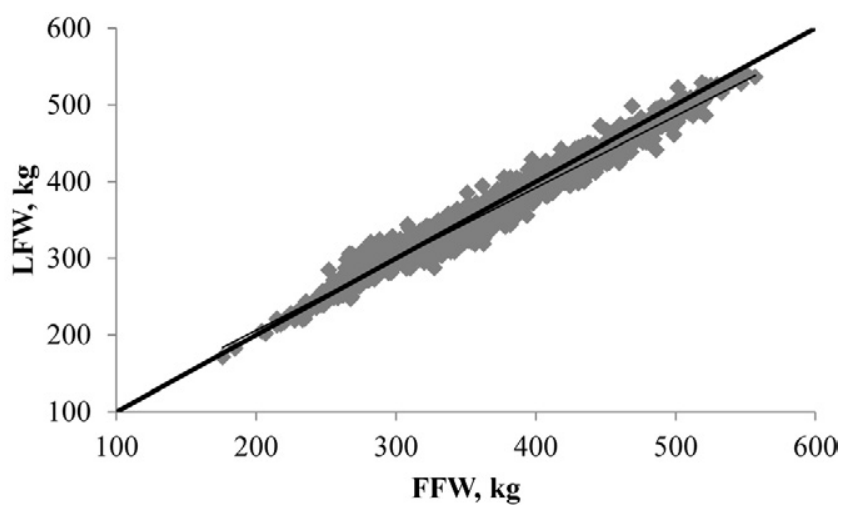

Figure 1. Relationship between weights taken on the same group of cattle using 2 different weighing procedures. Each point represents 1 animal on 1 of the 18 experiments. Limit-fed weights (LFW) are an average of 2 consecutive $d$ and were taken after a limit-feeding period. Full-fed weights (FFW) are an average of 2 consecutive $d$ in 10 experiments and a 1-d weight in 8 experiments. Points below the isopleth represent animals with FFW greater than LFW. Points above the isopleth represent animals with FFW less than LFW. $\mathrm{y}=0.93 \mathrm{x}+19.84 ; r^{2}=0.96$.

224 d, after which FFW were taken on 2 consecutive d. Cattle were then penned and limit fed for $7 \mathrm{~d}$, and LFW were taken on 2 consecutive $d$.

\section{Data Analysis}

Data were analyzed using the REG and GLIMMIX procedures of SAS (SAS Inst. Inc., Cary, NC). For each group of cattle, data were plotted with each animal's FFW as the independent variable on the $\mathrm{x}$ axis and LFW as the dependent variable on the y axis. Figure 1 contains all of the data from each of the 18 experiments as an example of how the data were plotted. Table 2 then shows data from each of the experiments plotted and analyzed separately. Relationships between FFW and LFW were examined by plotting a linear trend line. Standard errors of the slope and intercept of the lines are reported. Differences between FFW and LFW for each animal were calculated, and an average difference and range of differences are reported for each experiment.

The LFW data for all 18 groups of cattle were plotted with $\mathrm{d} 1 \mathrm{LFW}$ on the $\mathrm{x}$ axis and $\mathrm{d} 2 \mathrm{LFW}$ on the $\mathrm{y}$ axis (Figure 2; Table 3). The 10 experiments conducted at Kansas State University had FFW and LFW taken on 2 consecutive d. For these experiments, data were plotted with each animal's $d 1$ FFW on the $x$ axis and d 2 FFW on the $y$ axis (Fig. 3 and Table 4).For the 10 experiments conducted at Kansas State University equal slopes analysis was performed to determine if the slope of the line for FFW is different from the LFW slope (Table 2). Differences were considered significant with a $P$-value $\leq 0.10$.

In 15 of the experiments, beginning weights were taken and ADG was calculated. For 2 of these experiments (Exp. 6 and 8) FFW ADG was calculated using FFW for both beginning and ending weights, and LFW 
Table 2. Relationships between full-fed weights (FFW) and limit-fed weights (LFW) at the conclusion of 18 experiments ${ }^{1}$

\begin{tabular}{|c|c|c|c|c|}
\hline Exp. & $r^{2}$ & $\begin{array}{c}\text { Equation } \\
\left(\mathrm{SE}_{\mathrm{s}}^{2}\right)\left(\mathrm{SE}_{\mathrm{I}}^{3}\right) \\
\end{array}$ & $\begin{array}{c}\text { Avg difference, }{ }^{4} \mathrm{~kg} \\
\text { (Range) }\end{array}$ & $\begin{array}{c}\text { Equal slopes } \\
P \text {-value }\end{array}$ \\
\hline 1 & 0.946 & $\begin{array}{l}1.03 x-30.68 \\
(0.04)(18.79)\end{array}$ & $+16.8(-2.7,35.5)$ & 0.06 \\
\hline 2 & 0.894 & $\begin{array}{l}0.92 x+34.23 \\
(0.03)(15.11)\end{array}$ & $+5.0(-26.8,24.6)$ & 0.81 \\
\hline 3 & 0.803 & $\begin{array}{l}0.95 x+21.64 \\
(0.09)(34.49)\end{array}$ & $-2.3(-34.1,16.8)$ & 0.01 \\
\hline 4 & 0.906 & $\begin{array}{c}0.95 x+19.95 \\
(0.03)(9.93)\end{array}$ & $-3.7(-23.2,15.0)$ & 0.08 \\
\hline 5 & 0.977 & $\begin{array}{l}1.01 x-4.38 \\
(0.01)(2.77)\end{array}$ & $+4.6(-15.9,20.5)$ & $<0.01$ \\
\hline 6 & 0.943 & $\begin{array}{l}1.01 x-0.86 \\
(0.02)(6.14)\end{array}$ & $-2.1(-32.7,25.9)$ & $<0.01$ \\
\hline 7 & 0.751 & $\begin{array}{c}0.88 x+46.82 \\
(0.03)(9.26)\end{array}$ & $-12.5(-39.1,7.7)$ & $<0.01$ \\
\hline 8 & 0.859 & $\begin{array}{l}0.94 x+6.82 \\
(0.02)(5.96)\end{array}$ & $+15.5(-38.6,44.1)$ & 0.47 \\
\hline 9 & 0.951 & $\begin{array}{c}1.05 x-17.3 \\
(0.04)(15.43)\end{array}$ & $+0.5(-19.1,20.9)$ & 0.12 \\
\hline 10 & 0.963 & $\begin{array}{c}1.00 x-9.0 \\
(0.03)(12.63)\end{array}$ & $+9.2(-2.7,27.7)$ & 0.03 \\
\hline 11 & 0.967 & $\begin{array}{c}1.03 x-25.1 \\
(0.03)(12.64)\end{array}$ & $+14.6(-1.8,27.7)$ & 0.16 \\
\hline 12 & 0.954 & $\begin{array}{c}0.97 x+0.2 \\
(0.04)(14.17)\end{array}$ & $+11.5(-2.3,32.7)$ & 0.86 \\
\hline 13 & 0.980 & $\begin{array}{c}1.02 x-27.4 \\
(0.02)(10.45)\end{array}$ & $+17.1(+4.1,31.4)$ & 0.58 \\
\hline 14 & 0.966 & $\begin{array}{c}1.02 x-24.7 \\
(0.03)(13.32)\end{array}$ & $+18.5(+1.4,40.5)$ & 0.14 \\
\hline 15 & 0.883 & $\begin{array}{c}1.04 x-31.3 \\
(0.06)(27.67)\end{array}$ & $+11.1(0.5,26.4)$ & 0.21 \\
\hline 16 & 0.941 & $\begin{array}{c}0.97 \mathrm{x}-1.0 \\
(0.04)(17.40)\end{array}$ & $+12.2(+1.4,35.5)$ & 0.29 \\
\hline 17 & 0.912 & $\begin{array}{c}1.06 x-30.1 \\
(0.05)(25.01)\end{array}$ & $+3.1(-13.6,28.6)$ & 0.35 \\
\hline 18 & 0.954 & $\begin{array}{c}1.04 x-34.7 \\
(0.03)(12.57)\end{array}$ & $+14.1(-2.3,35.5)$ & 0.50 \\
\hline
\end{tabular}

${ }^{1}$ Full-fed weights (FFW) were measured while cattle had ad libitum intakes, limit fed weights (LFW) were measured after a 5-d period of restricting intakes to $2 \%$ of BW. Individual cattle BW were plotted with each animal's FFW as the independent variable on the $\mathrm{X}$ axis and LFW as the dependent variable on the $\mathrm{Y}$ axis, similar to Fig. 1.

${ }^{2}$ Standard error of the slope.

${ }^{3}$ Standard error of the intercept.

${ }^{4}$ Positive number indicates full weight greater than limit-fed weight; negative number indicates limit-fed weight greater than full weight.

${ }^{5} P>0.10$ indicates the slopes of FFW and LFW are not different from each other.

ADG was calculated using LFW for both beginning and ending weights. In the other 13 experiments only LFW were taken for beginning weights. For these experiments FFW ADG was calculated using LFW beginning weights and FFW ending weights. The LFW ADG was calculated using LFW beginning and ending weights. For each group of cattle, data were plotted with each
Table 3. Relationships between 2 consecutive $d$ of weights taken after a limit-feeding period (LFW) ${ }^{1}$

\begin{tabular}{|c|c|c|c|}
\hline Exp. & $r^{2}$ & $\begin{array}{c}\text { Equation } \\
\left(\mathrm{SE}_{\mathrm{S}}^{2}\right)\left(\mathrm{SE}_{\mathrm{I}}^{3}\right)\end{array}$ & $\begin{array}{c}\text { Avg difference, }{ }^{4} \\
\text { kg (Range) }\end{array}$ \\
\hline$\overline{1}$ & 0.973 & $\begin{array}{c}0.98 x+2.89 \\
(0.03)(11.63)\end{array}$ & $8.4(0.0,45.0)$ \\
\hline 2 & 0.971 & $\begin{array}{l}0.98 x+6.55 \\
(0.02)(7.91)\end{array}$ & $4.9(-20.0,15.5)$ \\
\hline 3 & 0.936 & $\begin{array}{l}1.08 x-35.25 \\
(0.05)(20.74)\end{array}$ & $6.5(-29.1,8.2)$ \\
\hline 4 & 0.939 & $\begin{array}{l}1.02 x-6.09 \\
(0.02)(8.46)\end{array}$ & $4.6(-15.5,15.5)$ \\
\hline 5 & 0.986 & $\begin{array}{l}1.01 x-1.96 \\
(0.01)(2.17)\end{array}$ & $3.8(-19.1,16.4)$ \\
\hline 6 & 0.977 & $\begin{array}{l}0.99 x-0.88 \\
(0.01)(3.77)\end{array}$ & $5.7(-15.5,23.6)$ \\
\hline 7 & 0.913 & $\begin{array}{c}0.94 x+17.50 \\
(0.02)(5.54)\end{array}$ & $3.9(-22.7,14.6)$ \\
\hline 8 & 0.927 & $\begin{array}{c}0.93 x+22.45 \\
(0.01)(3.94)\end{array}$ & $4.5(-21.8,15.5)$ \\
\hline 9 & 0.984 & $\begin{array}{l}0.97 x+8.05 \\
(0.02)(8.08)\end{array}$ & $4.6(-4.6,11.8)$ \\
\hline 10 & 0.994 & $\begin{array}{c}1.03 x-10.77 \\
(0.01)(5.00)\end{array}$ & $2.2(-7.7,5.0)$ \\
\hline 11 & 0.991 & $\begin{array}{l}1.01 x-9.23 \\
(0.02)(7.65)\end{array}$ & $6.0(-1.8,14.1)$ \\
\hline 12 & 0.987 & $\begin{array}{l}0.97 x+5.82 \\
(0.02)(7.27)\end{array}$ & $5.1(-2.7,13.2)$ \\
\hline 13 & 0.992 & $\begin{array}{l}1.01 x-7.36 \\
(0.02)(6.14)\end{array}$ & $3.8(-5.5,11.4)$ \\
\hline 14 & 0.974 & $\begin{array}{c}1.01 x+2.14 \\
(0.03)(10.95)\end{array}$ & $7.0(-17.7,10.5)$ \\
\hline 15 & 0.974 & $\begin{array}{l}1.04 x-17.86 \\
(0.03)(12.06)\end{array}$ & $3.0(-6.8,9.1)$ \\
\hline 16 & 0.983 & $\begin{array}{l}0.99 x+1.55 \\
(0.02)(8.87)\end{array}$ & $4.1(-4.6,12.3)$ \\
\hline 17 & 0.985 & $\begin{array}{l}0.97 x+7.32 \\
(0.02)(9.19)\end{array}$ & $7.4(-6.8,14.1)$ \\
\hline 18 & 0.991 & $\begin{array}{l}1.00 x-5.27 \\
(0.01)(5.02)\end{array}$ & $4.4(-5.9,11.4)$ \\
\hline
\end{tabular}

${ }^{1}$ Individual cattle BW were plotted with each animal's d 1 limit-fed weight (LFW) on the $\mathrm{x}$ axis and $\mathrm{d} 2 \mathrm{LFW}$ on the $\mathrm{y}$ axis, similar to Fig. 2.

${ }^{2}$ Standard error of the slope.

${ }^{3}$ Standard error of the intercept.

${ }^{4}$ Absolute difference.

animal's FFW ADG as the independent variable on the $\mathrm{x}$ axis and the LFW ADG as the dependent variable on the $y$ axis. All cattle are grouped together and plotted as an example of how data were analyzed (Fig. 4). Differences between FFW and LFW ADG were calculated, and an average difference and range of differences are reported for each trial (Table 5).

Out of the 15 experiments that were used to calculate ADG, 13 had 2 or more treatments applied. An $F$ test was used to compare ADG on a FFW and LFW basis to determine if statistical differences between treatments would 


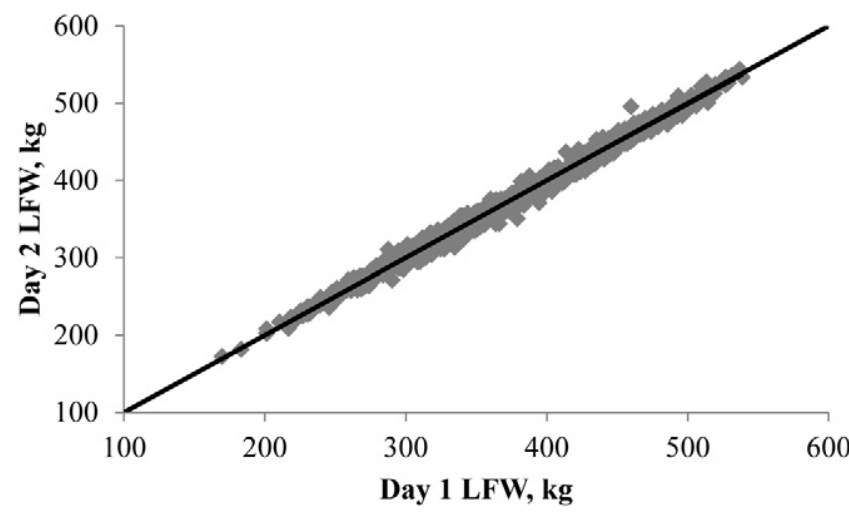

Figure 2. Relationship between weights taken on 2 consecutive $d$ after cattle were limit fed for $6 \mathrm{~d}$ (LFW). Each point represents 1 animal on 1 of the 18 experiments. $\mathrm{y}=0.99 \mathrm{x}+4.27 ; r^{2}=0.99$.

be impacted by weighing procedure. For this analysis differences were considered significant at $P \leq 0.05$ (Table 6).

\section{RESULTS AND DISCUSSION}

Many factors can affect animal weights and should be accounted for when measuring and reporting cattle weights. A limit-feeding protocol attempts to reduce variation in weights due to environmental conditions such as time of day, gut fill due to ad libitum intake, and how cattle are handled. Minimizing these factors is an attempt to measure live weight of the animal and predict empty body weight (EBW) of the animal. If this protocol is successful, accurate weights can be taken on large numbers of cattle on growing diets without having to slaughter the cattle.

\section{Differences between FFW and LFW}

Figure 1 shows data from all 18 experiments plotted to look at relationships between FFW and LFW. Data from each experiment were plotted individually, similar to Fig. 1, and are summarized in Table 2. Nine experiments (Exp. 1, 2, 5, 9, 10, 11, 12, 13, 14) consisting of 593 animals measured cattle weights after grazing smooth bromegrass pasture. Over all 9 experiments, the average difference between FFW and LFW was +10.9 $\mathrm{kg}$, with FFW being $10.9 \mathrm{~kg}$ greater than LFW (Table 2). The range of differences was -26.8 to $+40.0 \mathrm{~kg}$. Slopes of linear trend lines varied between 0.92 and 1.05 , with an average SE of 0.03. Seven experiments (Exp. 3, 4, 6, $15,16,17,18)$ consisting of 571 animals measured cattle weights after grazing Bermuda grass, fescue, or native range. Over all 7 experiments, the average difference between FFW and LFW was $+4.6 \mathrm{~kg}$, with FFW being 4.6 $\mathrm{kg}$ greater than LFW (Table 2). The range of differences was -34.1 to $+35.0 \mathrm{~kg}$. Slopes varied between 0.95 and 1.06 , with an average SE of 0.05. Experiment 7 measured

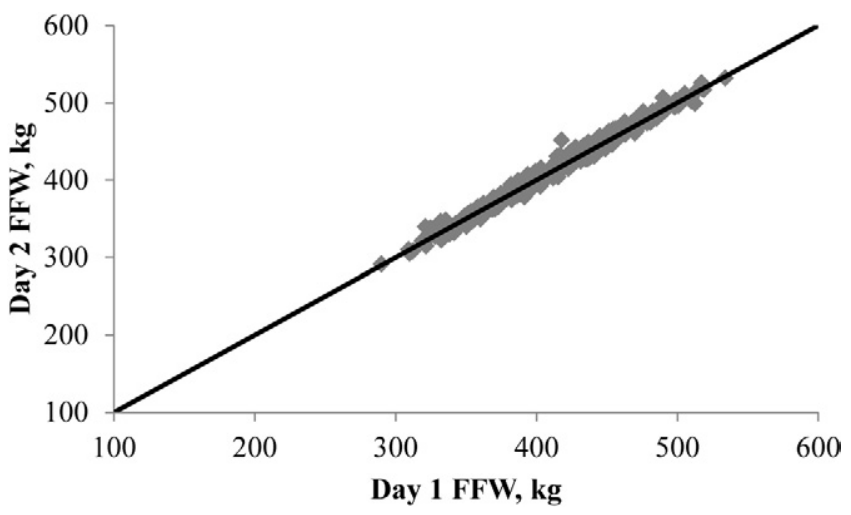

Figure 3. Relationship between weights taken on 2 consecutive d while cattle were fed ad libitum (FFW). Each point represents 1 animal on experiments 9 to $18 . \mathrm{y}=1.00 \mathrm{x}-0.94 ; r^{2}=0.99$.

cattle weights after 258 steers grazed cornstalk residue. The average difference between FFW and LFW was $-12.5 \mathrm{~kg}$, with FFW being $12.5 \mathrm{~kg}$ less than LFW (Table 2 ). The range of differences was -39.1 to $+7.7 \mathrm{~kg}$. Slope was 0.88 , with a $\mathrm{SE}$ of 0.03 . Experiment 8 measured cattle weights after 509 steers were on a forage-based growing trial. The average difference between FFW and LFW was $+15.5 \mathrm{~kg}$ and ranged between -38.6 and +44.1 $\mathrm{kg}$ (Table 2). Slope was 0.94 , with a SE of 0.02 .

In most experiments, the overall average FFW was numerically greater than LFW; however, in 4 of these experiments overall average $\mathrm{FFW}$ was numerically less than LFW (Exp. 3, 4, 6, and 7; Table 2). In every experiment there was at least 1 animal with a FFW numerically less than its LFW. Within this data set there is not a consistent relationship between FFW and LFW, which suggests that FFW are highly variable and dependent on many environmental conditions. By controlling, or at least documenting, the environmental conditions at weighing, cattle weights become more relevant and useful.

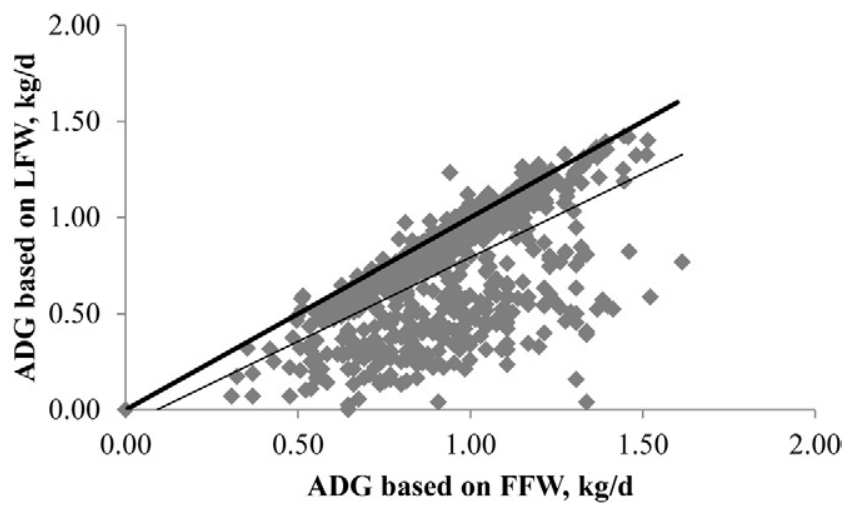

Figure 4. Relationship between ADG calculated from weights taken using 2 different weighing procedures. Each point represents 1 animal on Exp. $1,2,8$, or 9 to 18 . Weights were taken while cattle were being fed ad libitum (FFW) and after a limit-feeding period (LFW). Points below the isopleth represent animals with FFW ADG greater than LFW ADG. Points above the isopleth represent animals with FFW ADG less than LFW ADG. $y=0.87 \mathrm{x}$ $-0.079 ; r^{2}=0.42$. 
Table 4. Relationships between 2 consecutive $d$ of weights taken while cattle had ad libitum intakes (FFW $)^{1}$

\begin{tabular}{lccc}
\hline \hline Exp. & $r^{2}$ & $\begin{array}{c}\text { Equation } \\
\left(\mathrm{SE}_{\mathrm{S}}{ }^{2}\right)\left(\mathrm{SE}_{\mathrm{I}}^{3}\right)\end{array}$ & $\begin{array}{c}\text { Avg difference, }{ }^{4} \mathrm{~kg} \\
\text { (Range) }\end{array}$ \\
\hline 9 & 0.985 & $\begin{array}{l}1.02 \mathrm{x}-8.32 \\
(0.02)(8.09)\end{array}$ & $3.7(-10.9,9.1)$ \\
& & $\begin{array}{c}0.97 \mathrm{x}+10.27 \\
(0.02)(8.36)\end{array}$ & $3.3(-8.2,12.3)$ \\
10 & 0.982 & $\begin{array}{c}0.97 \mathrm{x}+14.77 \\
(0.02)(6.19)\end{array}$ & $5.5(-10.9,5.5)$ \\
& & $0.98 \mathrm{x}+7.05$ & $4.6(-10.5,18.2)$ \\
11 & 0.986 & $(0.03)(12.62)$ & \\
& & $1.00 \mathrm{x}-2.82$ & $6.4(-10.0,15.9)$ \\
12 & 0.964 & $(0.02)(10.43)$ & \\
& & $0.95 \mathrm{x}+20.86$ & $4.8(-13.6,12.3)$ \\
13 & 0.996 & $(0.02)(9.93)$ & \\
& & $0.97 \mathrm{x}+11.73$ & $6.0(-9.1,5.9)$ \\
14 & 0.978 & $(0.05)(23.54)$ & \\
& & $0.95 \mathrm{x}+19.36$ & $4.0(-9.1,10.9)$ \\
15 & 0.901 & $(0.03)(11.17)$ & \\
& & $1.00 \mathrm{x}-0.23$ & $3.0(-13.6,6.8)$ \\
16 & 0.973 & $(0.03)(12.00)$ & \\
& & $1.02 \mathrm{x}-10.59$ & $4.6(-8.6,34.1)$ \\
17 & 0.976 & $(0.02)(9.45)$ & \\
& & &
\end{tabular}

${ }^{1}$ Individual cattle BW were plotted with each animal's d 1 full-fed weight (FFW) on the $\mathrm{x}$ axis and $\mathrm{d} 2 \mathrm{FFW}$ on the y axis, similar to Fig. 3.

${ }^{2}$ Standard error of the slope.

${ }^{3}$ Standard error of the intercept.

${ }^{4}$ Absolute difference.

One potential source of variation in LFW is due to group feeding and cattle not all consuming exactly $2 \%$ of BW in feed each day. This is overcome by having at least $5 \mathrm{~d}$ of limit feeding and, more important, allowing cattle at least $0.41 \mathrm{~m}$ (16 inches) of space at the bunk. Research on bunk management has found no difference in ADG and feed efficiency when cattle are allowed 0.15 to $0.60 \mathrm{~m}$ of bunk space, even when being limit fed (Gunter et al., 1996; Zinn, 1989).

In all 18 experiments, LFW were an average of weights taken on 2 consecutive d. In 10 experiments, FFW were also an average of weights taken on 2 consecutive d. Figure 2 shows data plotted to look at relationships between LFW taken on consecutive days, and Fig. 3 shows data plotted to look at relationships between FFW taken on consecutive days. Figures 2 and 3 include data combined from all experiments; data from each individual experiment are summarized in Tables 3 and 4. Two consecutive days of LFW were strongly associated within each experiment, with $r^{2} \geq 0.93$ and ranging from 0.93 to 0.99 . The average difference between LFW on different days was $5.2 \mathrm{~kg}$ and ranged from -29.1 to $+45.0 \mathrm{~kg}$ for individual animals (Table 3). For the 10 experiments conducted at Kansas State University the 2 consecutive d of FFW were also highly related, with $r^{2} \geq 0.90$ and ranging from 0.90 to 0.99 . The average dif-
Table 5. Relationships between ADG calculated from LFW or FFW ${ }^{1}$

\begin{tabular}{|c|c|c|c|c|c|}
\hline Exp. & $\begin{array}{c}\text { Full ADG, } \\
\text { kg/d (Range) }\end{array}$ & $\begin{array}{c}\text { LF ADG, } \\
\text { kg/d (Range) }\end{array}$ & $\begin{array}{c}\text { Avg difference, } \\
\text { kg/d (Range) }\end{array}$ & $\overline{r^{2}}$ & $\begin{array}{c}\text { Equation } \\
\left(\mathrm{SE}_{\mathrm{S}}^{3}\right)\left(\mathrm{SE}_{\mathrm{I}}^{4}\right)\end{array}$ \\
\hline $6^{5}$ & $\begin{array}{c}0.67 \\
(0.33,1.06)\end{array}$ & $\begin{array}{c}0.70 \\
(0.34,1.18)\end{array}$ & $\begin{array}{c}-0.035 \\
(-0.249,0.190)\end{array}$ & 0.77 & $\begin{array}{l}1.05 x+0.005 \\
(0.04)(0.023)\end{array}$ \\
\hline $8^{5}$ & $\begin{array}{c}0.91 \\
(0.31,1.62)\end{array}$ & $\begin{array}{c}0.42 \\
(-0.05,0.95)\end{array}$ & $\begin{array}{c}0.486 \\
(0.033,1.299)\end{array}$ & 0.40 & $\begin{array}{l}0.51 x-0.041 \\
(0.04)(0.036)\end{array}$ \\
\hline $1^{6}$ & $\begin{array}{c}0.91 \\
(0.50,1.39)\end{array}$ & $\begin{array}{c}0.81 \\
(0.46,1.39)\end{array}$ & $\begin{array}{c}0.099 \\
(0.0,0.267)\end{array}$ & 0.94 & $\begin{array}{l}1.04 x-0.132 \\
(0.04)(0.041)\end{array}$ \\
\hline $2^{6}$ & $\begin{array}{c}1.01 \\
(0.50,1.52)\end{array}$ & $\begin{array}{c}0.99 \\
(0.49,1.42)\end{array}$ & $\begin{array}{c}0.025 \\
(-0.292,0.145)\end{array}$ & 0.89 & $\begin{array}{l}0.92 x+0.059 \\
(0.04)(0.041)\end{array}$ \\
\hline 36 & $\begin{array}{c}0.62 \\
(0.14,0.98)\end{array}$ & $\begin{array}{c}0.64 \\
(0.34,1.11)\end{array}$ & $\begin{array}{c}-0.019 \\
(-0.281,0.139)\end{array}$ & 0.78 & $\begin{array}{l}0.94 x+0.059 \\
(0.09)(0.059)\end{array}$ \\
\hline $9^{6}$ & $\begin{array}{c}0.90 \\
(0.51,1.19)\end{array}$ & $\begin{array}{c}0.91 \\
(0.53,1.23)\end{array}$ & $\begin{array}{c}-0.002 \\
(-0.097,0.106)\end{array}$ & 0.95 & $\begin{array}{l}1.03 x-0.027 \\
(0.04)(0.036)\end{array}$ \\
\hline $10^{6}$ & $\begin{array}{c}0.94 \\
(0.58,1.30)\end{array}$ & $\begin{array}{c}0.89 \\
(0.52,1.23)\end{array}$ & $\begin{array}{c}0.056 \\
(-0.015,0.171)\end{array}$ & 0.95 & $\begin{array}{l}1.00 x-0.059 \\
(0.04)(0.036)\end{array}$ \\
\hline $11^{6}$ & $\begin{array}{c}0.87 \\
(0.42,1.22)\end{array}$ & $\begin{array}{c}0.79 \\
(0.31,1.16)\end{array}$ & $\begin{array}{c}0.080 \\
(-0.009,0.151)\end{array}$ & 0.96 & $\begin{array}{l}1.05 x-0.118 \\
(0.04)(0.032)\end{array}$ \\
\hline $12^{6}$ & $\begin{array}{c}0.93 \\
(0.67,1.19)\end{array}$ & $\begin{array}{c}0.88 \\
(0.57,1.14)\end{array}$ & $\begin{array}{c}0.059 \\
(-0.010,0.165)\end{array}$ & 0.94 & $\begin{array}{l}1.00 x-0.059 \\
(0.04)(0.041)\end{array}$ \\
\hline $13^{6}$ & $\begin{array}{c}0.92 \\
(0.57,1.22)\end{array}$ & $\begin{array}{c}0.84 \\
(0.49,1.15)\end{array}$ & $\begin{array}{c}0.077 \\
(0.019,0.140)\end{array}$ & 0.97 & $\begin{array}{l}1.03 x-0.100 \\
(0.03)(0.027)\end{array}$ \\
\hline $14^{6}$ & $\begin{array}{c}0.90 \\
(0.66,1.19)\end{array}$ & $\begin{array}{c}0.82 \\
(0.54,1.13)\end{array}$ & $\begin{array}{c}0.083 \\
(0.003,0.178)\end{array}$ & 0.95 & $\begin{array}{l}1.00 x-0.086 \\
(0.04)(0.036)\end{array}$ \\
\hline $15^{6}$ & $\begin{array}{c}1.22 \\
(0.96,1.51)\end{array}$ & $\begin{array}{c}1.10 \\
(0.80,1.42)\end{array}$ & $\begin{array}{c}0.124 \\
(0.003,0.290)\end{array}$ & 0.75 & $\begin{array}{l}1.00 \mathrm{x}-0.122 \\
(0.09)(0.122)\end{array}$ \\
\hline $16^{6}$ & $\begin{array}{c}0.90 \\
(0.54,1.32)\end{array}$ & $\begin{array}{c}0.80 \\
(0.44,1.18)\end{array}$ & $\begin{array}{c}0.108 \\
(0.010,0.313)\end{array}$ & 0.91 & $\begin{array}{l}0.98 x-0.086 \\
(0.05)(0.450)\end{array}$ \\
\hline $17^{6}$ & $\begin{array}{c}0.95 \\
(0.49,1.37)\end{array}$ & $\begin{array}{c}0.92 \\
(0.38,1.36)\end{array}$ & $\begin{array}{c}0.029 \\
(-0.126,0.269)\end{array}$ & 0.90 & $\begin{array}{l}1.10 x-0.122 \\
(0.06)(0.054)\end{array}$ \\
\hline $18^{6}$ & $\begin{array}{c}0.92 \\
(0.56,1.18)\end{array}$ & $\begin{array}{c}0.86 \\
(0.45,1.16)\end{array}$ & $\begin{array}{c}0.063 \\
(-0.009,0.157)\end{array}$ & 0.95 & $\begin{array}{l}1.05 x-0.109 \\
(0.03)(0.027)\end{array}$ \\
\hline
\end{tabular}

${ }^{1}$ Full-fed weights (FFW) were measured while cattle had ad libitum intakes; limit-fed weights (LFW) were measured after a 5 -d period of restricting intakes to $2 \%$ of BW. Individual cattle BW were plotted with each animal's FFW ADG as the independent variable on the $\mathrm{x}$ axis and LFW ADG as the dependent variable on the y axis, similar to Fig. 4.

${ }^{2}$ Positive number indicates full ADG greater than limit-fed ADG; negative number indicates limit-fed ADG greater than full ADG.

${ }^{3}$ Standard error of the slope.

${ }^{4}$ Standard error of the intercept.

${ }^{5}$ Indicates ADG calculated from full- and limit-fed beginning and ending weights.

${ }^{6}$ Indicates ADG calculated from limit-fed beginning weights and limit-fed and full-fed ending weights.

ference between FFW on different days was $4.6 \mathrm{~kg}$ and ranged from -13.6 to +34.1 (Table 4 ). For these same 10 experiments, the average difference in LFW on different days averaged $5.2 \mathrm{~kg}$ and ranged from -17.7 to +14.1 (Table 3). Equal slopes analysis was used to compare the slope of the line through the 2-d FFW data to the slope of the line through the 2-d LFW data for each individual experiment. The range in $P$-values was $<0.01$ to 0.86 (Table 2). In 8 of the experiments the slopes of the lines were not different from each other $(P>0.20)$. Slopes of the lines were different in 7 of the experiments $(P<0.10)$. The remaining 3 experiments had intermediate $P$-values 
Table 6. Statistical differences in ADG due to LFW or FFW weighing procedure ${ }^{1}$

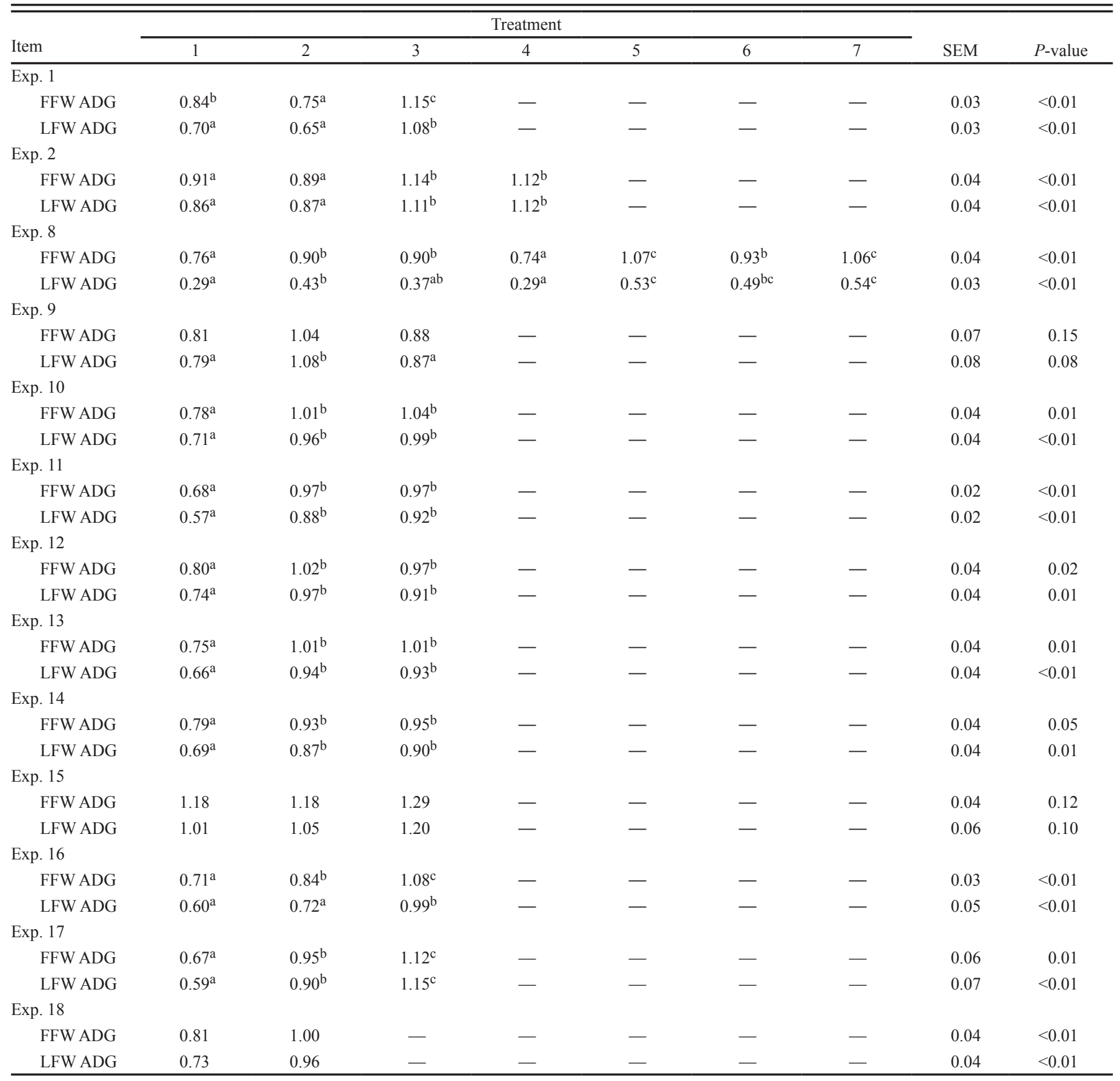

${ }^{\mathrm{a}-\mathrm{c}}$ Within a row, means without a common superscript differ $(P<0.05)$.

${ }^{1}$ Full-fed weights (FFW) were measured while cattle had ad libitum intakes; limit-fed weights (LFW) were measured after a 5-d period of restricting intakes to $2 \%$ of $\mathrm{BW}$.

of 0.12 to 0.16 . In experiments where slopes were not significantly different FFW could be adjusted to LFW. However, this analysis demonstrates that unless cattle are limit fed there is no clear way of determining if FFW and LFW would be similar; under some conditions, FFW and LFW may not be significantly different. Relative differences between 2-d weights were consistent when cattle were handled in a similar manner, regardless of intake level. These experiments were all conducted in pasture grazing systems where treatment would not be expected to affect gut fill. Without EBW measurements on these cattle it is unclear if LFW or FFW are more accurate or closer to actual body tissue weight. 


\section{Differences in ADG due to Weighing Procedure}

In 15 experiments, beginning and ending weights were used to calculate ADG. Figure 4 shows data for all 15 experiments combined; data from each experiment were plotted individually for analysis, and results are summarized in Table 5. Over all 15 experiments, FFW ADG was $0.082 \mathrm{~kg} / \mathrm{d}$ greater than LFW ADG and ranged between -0.292 and $+0.313 \mathrm{~kg} / \mathrm{d}$ for individual animals. Slopes ranged from 0.51 to 1.10 , with an average SE of 0.047. Differences in both beginning and ending weights are compounded when calculating ADG, which is reflected in the $r^{2}$ of 0.40 to 0.97 . Shorter treatment periods also exaggerate these differences in ADG. By spreading weights out over a longer period, variation in weights due to weighing procedure can be overcome (Stock et al., 1983). Experiment 8, with both FFW and LFW ADG measured on 258 out of 509 steers on a forage-based growing diet, had the weakest relationship between FFW ADG and LFW ADG at $r^{2}=0.40$ (Table 5). For this experiment the trend line is not parallel to the isopleth, suggesting that as gains increase, the error in measuring that gain increases as well. This illustrates that applying a 4\% shrink uniformly across all cattle will not correctly adjust full weights to a limit-fed basis. For these 18 experiments, shrink from FFW to LFW ranged between $-4.8 \%$ and $+6.8 \%$. Shrink measured on 16,590 cattle by Cernicchiaro et al. (2012) ranged between $-5.8 \%$ and $+14.8 \%$.

Evaluating individual animals within this experiment illustrates that some measured gains are not biologically plausible. For example, 1 animal had a FFW ADG of $1.62 \mathrm{~kg} / \mathrm{d}$. This animal was on a low-quality, $70 \%$ crop residue diet. This animal's LFW ADG of $0.77 \mathrm{~kg} / \mathrm{d}$ is likely more accurate. Another animal with a large variation between weights had a FFW ADG of 1.34 and LFW ADG of $0.04 \mathrm{~kg} / \mathrm{d}$. These large changes in measuring ADG could easily change conclusions from this research and affect the outcome and profitability of producers using this information.

Weights taken on consecutive days while cattle were limit fed were highly correlated. Accurate weights help identify small statistical differences between treatments. Just as important, accurate weights help prevent type I statistical errors or concluding there are differences between treatments when in fact there are not. Table 6 shows statistical differences between treatments based on either FFW ADG or LFW ADG for Exp. 1, 2, and 8 to 18. For Exp. 1, FFW data show that ADG is greater for treatment 1 than treatment 2. Using LFW data, the conclusion is that ADG is equal for the 2 treatments. In Exp. 2, 10 to 15, 17, and 18 there are no changes in statistical differences between treatments for LFW ADG compared to FFW ADG. However, the different treatments respond dif- ferently to limit feeding, with FFW ADG being $0 \%$ to $15.4 \%$ greater than LFW ADG. Using FFW or LFW to calculate ADG also changes the conclusions drawn about treatments in Exp. 8, 9, and 16.

\section{Components of Limit-Fed Weighing Procedure}

Differences observed between FFW and LFW in this study may be a function of both the limit-feeding phase and using multiple-day weights to measure LFW. There are many versions of limit feeding, but most recommend taking multiple weights to overcome day-to-day variation and more accurately identify BW. There is a balance needed between weighing on multiple days to obtain accurate weights and weighing too many days, resulting in unnecessary stress on the cattle. Most research that has been done on multiple-day weights agrees that 2 or 3 consecutive days of weights are adequate but not excessive (Koch et al., 1958; Stock et al., 1983; GutierrezOrnelas and Klopfenstein, 1991). Weighing more frequently can be used to decrease variation, which can allow for fewer animals on an experiment (Lush et al., 1928; Baker and Guilbert, 1942). With recent advances in technology it is possible to measure full weights of cattle multiple times per day, every day of a trial, without removing them from the pen. This method yields multiple weights per day over an extended period of time, which yields so many measurements that it is possible to overcome variation due to gut fill (Charmley et al., 2006; Kolath et al., 2007).

The second component of the limit-feeding procedure limits intake of a constant ration to limit fill effects and eliminate fill effects due to diet (Meyer et al., 1960). Limit feeding does not constrain water intake but instead allows cattle equal access to water at all times, as recommended by Whiteman et al. (1954). Shrink occurs most rapidly during the first 3 to $4 \mathrm{~h}$ of feed and water restriction and generally slows down after the initial loss (Cole et al., 1988; Coffey et al., 1997). For this limit-feeding procedure, cattle are typically restricted from feed for $18 \mathrm{~h}$ before being weighed. Limit feeding does not limit shrink from occurring but, instead, attempts to standardize shrink by exposing cattle to the same environmental conditions, handling, and diet.

The 10 pasture experiments conducted at Kansas State University demonstrate differences in weights due to differences in intake. Cattle were handled in a similar manner for FFW and LFW. Weights were taken at approximately $0800 \mathrm{~h}$, and cattle were on forage-based diets and were not moved long distances. Variation within the $2 \mathrm{~d}$ of FFW was very similar to variation within the 2 $\mathrm{d}$ of LFW. Conversely, cattle on the 8 experiments conducted at University of Nebraska were handled very differently for FFW and LFW. For some experiments, FFW 
were measured after cattle were moved up to $1.6 \mathrm{~km}$ on foot or shipped up to $322 \mathrm{~km}$ in semitrucks. For each of these 8 experiments, cattle were then handled very similarly on both days of LFW. The limit-fed weighing procedure is comprised of 2 parts: handling the cattle in the same way on 2 consecutive $d$ of weights being taken and restricting cattle intakes to $2 \%$ of BW. It appears that handling the cattle in a similar manner when weighing is more important than limiting intakes to decrease variance between weights. Limiting intakes is important to measure weights that are close to EBW and to standardize shrink across all cattle.

In systems research, cattle are handled differently during each phase of the system. Allowing for a limitfed period between phases where cattle are on a common diet is crucial for determining actual body tissue gain for each phase. If cattle are weighed off cornstalks and put directly on smooth bromegrass without LFW, ADG will be misrepresented for each portion of the system. Accurate weights are more difficult to obtain with forage-based growing diets than in feedlot settings with high-concentrate diets (Koch et al., 1958). Larger variations in gut fill are seen with forage-based diets, and correctly weighing cattle off of growing experiments can be much more challenging than weighing cattle after finishing experiments where $\mathrm{HCW}$ can be used (Meyer et al., 1960). Typically, cattle are treated similarly before beginning weights are taken, and it is ending weights that can be problematic as treatments can often influence gut fill. The only way to eliminate gut fill differences is to slaughter cattle and measure EBW. By standardizing final weights with the use of carcass weights, beginning weights become the most important measurement and the source of error in calculating ADG (Meyer et al., 1960). Excessive trim is a concern when utilizing carcass weights but can be avoided with careful technique.

\section{Conclusions}

Accurate weights are crucial for research and are equally important in industry settings. The financial impact of inaccurate weights can be substantial in both industry and research situations. A standard protocol for weighing cattle is critical to compare cattle weights across treatments, systems, locations, or research stations. Obtaining accurate weights can be challenging, but every effort should be made to minimize variation due to gut fill, technique error, and environmental conditions. By limit feeding cattle on a common diet and then weighing early in the morning on 2 consecutive d, variation in gut fill and differences due to environment can be minimized. The experiments included in this analysis did not measure EBW of cattle, so no conclusion can be drawn as to how correlated either LFW or FFW are to
EBW. It is clear that the relationship between LFW and FFW is not consistent; thus, a standard weighing procedure is needed if actual cattle weights and gains are to be compared across systems and locations.

\section{LITERATURE CITED}

Baker, G. A., and H. R. Guilbert. 1942. Non-randomness of variations in daily weights of cattle. J. Anim. Sci. 1:293-299.

Cernicchiaro, N., B. J. White, D. G. Renter, A. H. Babcock, L. Kelly, and R. Slattery. 2012. Effects of body weight loss during transit from sale barns to commercial feedlots on health and performance in feeder cattle cohorts arriving to feedlots from 2000 to 2008. J. Anim. Sci. 90:1940-1947.

Charmley, E., T. L. Gowan, and J. L. Duynisveld. 2006. Development of a remote method for the recording of cattle weights under field conditions. Aust. J. Exp. Agric. 46:831-835.

Coffey, K. P., F. K. Brazle, J. J. Higgins, and J. L. Moyer. 1997. Effects of gathering time on weight and shrink of steers grazing smooth bromegrass pastures. Prof. Anim. Sci. 13:170-175.

Cole, N. A., T. H. Camp, L. D. Rowe Jr., D. G. Stevens, and D. P. Hutcheson. 1988. Effect of transportation on feeder calves. Am. J. Vet. Res. 49:178-183.

Gunter, S. A., M. L. Galyean, and K. J. Malcolm-Callis. 1996. Factors influencing the performance of feedlot steers limit-fed high-concentrate diets. Prof. Anim. Sci. 12:167-175.

Gillespie, K. L., T. J. Klopfenstein, J. A. Musgrave, B. L. Nuttelman, C. J. Schneider, L. A. Stalker, and J. D. Volesky. 2012. Replacement of grazed forage and animal performance when distillers grains are fed in a bunk or on the ground. J. Anim. Sci. 90(Suppl. 2):104. (Abstr.)

Gutierrez-Ornelas, E., and T. J. Klopfenstein. 1991. Diet composition and gains of escape protein-supplemented growing cattle grazing corn residues. J. Anim. Sci. 69:2187-2195.

Koch, R. M., E. W. Schleicher, and V. H. Arthaud. 1958. The accuracy of weights and gains of beef cattle. J. Anim. Sci. 17:604-611.

Kolath, W. H., C. Huisma, and M. S. Kerley. 2007. Case study: An evaluation of the potential to measure real-time body weight of feedlot cattle. Prof. Anim. Sci. 23:295-299.

Lomas, L. W., and J. L. Moyer. 2009. Supplementation of grazing stocker cattle with distillers grains. In: Agricultural research 2009. Rep. of Progress No. 1013. Kansas Agric. Exp. Stn., Manhattan.

Lomas, L. W., and J. L. Moyer. 2011a. Distillers grains supplementation strategy for grazing stocker cattle. In: Agricultural research 2011. Rep. of Progress No. 1051. Kansas Agric. Exp. Stn., Manhattan. .

Lomas, L. W., and J. L. Moyer. 2011b. Effect of cultivar and distillers grains supplementation on grazing and subsequent finishing performance of stocker steers grazing tall fescue pasture. In: Agricultural research 2011. Rep. of Progress No. 1051. Kansas Agric. Exp. Stn., Manhattan. .

Lush, J. L., F. W. Christensen, and W. H. Black. 1928. The accuracy of cattle weights. J. Agric. Res. 36:551--580.

Meyer, J. H., G. P. Lofgreen, and W. N. Garrett. 1960. A proposed method for removing sources of error in beef cattle feeding experiments. J. Anim. Sci. 19:1123-1131.

Patterson, R. E. 1947. The comparative efficiency of single versus threeday weights of steers. J. Anim. Sci. 6:237-246.

Pruitt, S. K., K. M. Rolfe, B. L. Nuttelman, T. J. Klopfenstein, G. E. Erickson, W. A. Griffin, and W. H. Schacht. 2012. Strategies of supplementing dried distillers grains to yearling steers on smooth bromegrass pastures. In: 2012 Nebraska Beef Cattle Report. Rep. No. MP 95. Univ. of Nebraska-Lincoln, Lincoln. p. 49-50. 
Stock, R., T. J. Klopfenstein, D. Brink, S. Lowry, D. Rock, and S. Abrams. 1983. Impact of weighing procedures and variation in protein degradation rate on measured performance of growing lambs and cattle. J. Anim. Sci. 57:1276-1285.

Watson, A. K., T. J. Klopfenstein, W. H. Schacht, G. E. Erickson, D. R. Mark, M. K. Luebbe, K. R. Brink, and M. A. Greenquist. 2012. Smooth bromegrass pasture beef growing systems: Fertilization strategies and economic analysis. Prof. Anim. Sci. 28:443-451.
Weber, B. M., B. L. Nuttelman, K. R. Rolfe, C. J. Schneider, G. E. Erickson, T. J. Klopfenstein, and W. A. Griffin. 2012. Effects of forage type, storage method, and moisture level in crop residues mixed with modified distillers grains. In: 2012 Nebraska Beef Cattle Report. Rep. No. MP 95. Univ. of Nebraska-Lincoln, Lincoln. p. 55-57.

Whiteman, J. V., P. F. Loggins, D. Chambers, L. S. Pope, D. F. Stephens. 1954. Some sources of error in weighing steers off grass. J. Anim. Sci. 13:832-842.

Zinn, R. A. 1989. Manger space requirements for limit-fed feedlot steers. J. Anim. Sci. 67:853-857. 